\title{
Physico-chemical aspects of grape juices produced in the region of Campanha Gaucha, RS, Brazil (Southern Brazil)
}

\author{
V.B. Costa ${ }^{1}$, S.B. de Andrade ${ }^{2}$, P.L.P.K. Lemos ${ }^{3}$, A. Bender ${ }^{2}$, C. Goulart ${ }^{2}$, and F.G. Herter ${ }^{2}$ \\ ${ }^{1}$ Federal University of Pampa, Campus Dom Pedrito, Vinte e Um de Abril, 80 - São Gregório, 96450-000, Dom Pedrito, RS - Brazil \\ ${ }^{2}$ Federal University of Pelotas, Campus Universitário, S/N - 96160-000, Capão do Leão, RS - Brazil \\ ${ }^{3}$ KU Leuven, Faculty of Engineering Technology, 9000, Ghent, Belgium
}

\begin{abstract}
The Campanha Gaucha region, southern Brazil, has received significant investments in Viticulture during the last decades, especially for the production of quality wines. However, implementing the production of American and hybrid grapes in this region constitutes and opportunity to supply the increasing demand of the grape juice market in Brazil. Juices of two varieties, "Bordô" and "Concord", from two locations, Dom Pedrito and Santana do Livramento, were analysed in terms of the following physico-chemical aspects: total city, volatile acidity, density, $\mathrm{pH}$, soluble solids content, color intensity, and hue. "Bordô" juices presented higher total acidity and did not differ in relation to location. Higher volatile acidity was found in "Concord" juice from Santana do Livramento. Higher $\mathrm{pH}$ was found in the variety "Concord" and in the location Dom Pedrito. For this same location, the "Concord" grape juices showed higher soluble solids values. Color intensity was higher in Santana do Livramento. Color hue was higher in Dom Pedrito. Both variety and location impacted significantly on physico-chemical aspects of grape juices, although all the grapes were produced within the Campanha Gaucha region.
\end{abstract}

\section{Introduction}

\subsection{Grape juice in Brazil}

Grape juice market has been increasing steadily during the last two decades in Brazil and expanded more than 3-fold from 2004 to 2012, in the State of Rio Grande do Sul (RS). This state is responsible for $90 \%$ of the grapederived national products and thus data from this single State is representative for the whole country. A remarkable trend towards the consumption of the juice type "Integral" (whole juice) was observed more recently, shifting from 31 Million liters in 2010 to 108 Million liters in 2015, a 2.4-fold growth within 5 years. Grape juice is also included by law in the list of meals for public schools of the two southernmost states of Brazil, what contributes to leverage sales [1-4].

\subsection{American and hybrid varieties as main raw material}

The production of grape juice has been an alternative to sustain the viticulture in the country. It employs as raw materials American and hybrid grape varieties that traditionally also give origin to non-quality wines, whose acceptance by consumers has been in decline [2]. These varieties represent $80 \%$ of Brazilian national grape production and originate juices with optimal sensory characteristics and equilibrium between sweetness and acidity [5]. The most important varieties traditionally grown and used for juice production are "Isabel", "Concord", and "Bordô" [6]. They present good resistance against diseases caused by fungi and chromista, when compared to Vitis vinifera varieties [7]. The control of diseases becomes more difficult along the successive chemical control procedures as the pathogens acquire resistance against the active principles. These tends to lead to the utilization of more agrochemicals [8]. Nevertheless, the organic production systems have been an increasing trend lately [9]. It justifies the interest in implementing such systems in regions where the abiotic conditions are more favorable.

\subsection{Producing regions - Serra}

The Serra Gaúcha region, located in the state of Rio Grande do Sul, is currently and historically the main region for viticulture in Brazil, where a large number of small farmers is dedicated to grow vines mostly on rocky soils of steep slopes, which make mechanization limited [1]. Tonietto et al. [10] highlight that, in this region, the rain distributed throughout the cycle of the crop and the high humidity trigger the occurrence of fungal diseases, which can be considered the main causes of variation between the production cycles both quantitatively and qualitatively. The grape juices produced in this region with the American and hybrid grape varieties have a good equilibrium of sweetness and acidity.

\subsection{Producing regions - Campanha}

Another important region named Campanha Gaúcha has attracted increasing attention and investments on viticulture during the last decades. Its conditions of soil and weather have proven to favourable for the production of quality wines within the southernmost state of Brazil: sandy well drained soils of low natural fertility; high 
solar radiation and low pluviosity during maturation period (Dec-Feb); relatively warm and dry conditions during the vegetative period (Aug-Mar); appreciable daily temperature amplitude; and the relief is composed of very gentle slopes, what allows the wind to flow and partially remove the humidity [11].

More than 740 hours of sunshine and low pluviosity $(330 \mathrm{~mm})$ between December and February provide adequate conditions for berry maturation and the appreciable daily temperature amplitude (cooler nights) is positively related to the accumulation of sugars and polyphenols, specially anthocyanins [11,12]. The anthocyanins are directly linked, among others, with the colour attributes of grape juices [13]. The amounts of sugars in grape juices must be within the limits specified in the legislation, as well as the relation ${ }^{\circ}$ Brix/acidity, which are fundamental attributes determining the sensory profile $[14,15]$.

Temperatures over $10^{\circ} \mathrm{C}$ (the basal temperature of grapevines) are fundamental for the vegetative development. The low humidity and high solar radiation impart lower incidence of diseases and allow a lower use of agrochemicals. The relief and the training systems allow mechanization $[11,12]$.

\subsection{Comparison between the regions}

As the Serra Gaúcha region is the most important region for viticulture in the country and the Campanha Gaúcha region has no tradition in grape juice production, it is interesting to compare both in terms of some relevant aspects. The last region produces grapes, juices, and wines at lower costs and with distinct sensory characteristics [12]. Rizzon et al. [14] found that musts and wines of Vitis vinifera grapes grown in Santana do Livramento (the city where some of the samples for the present study were collected) were characterized by significantly higher values of $\mathrm{pH}$ and lower values of total acidity when compared with those from Bento Gonçalves (Serra Gaúcha). Rizzon and Link [15] mention that the juice obtained from the variety "Isabel" from the Serra Gaucha present high acidity. No studies comparing musts or juices from the different locations within the studied region were found in the literature.

\subsection{Lack of research for grape juice in the region}

The production of grape juices from grape vines grown the Campanha Gaúcha region, both in conventional and organic systems, is already carried out by a few research institutions, companies, and agricultural cooperative associations. All these organizations stimulate the promising activities of the sector [16], which are still incipient and lack scientific studies covering specifically this area.

\subsection{Objective}

The objective of the present study was to analyze the physicochemical aspects of the grape juice obtained from different variety produced in different locations in the region of Campanha Gaucha, RS, Brazil.

\section{Methodology}

The experiment was performed in the harvest of 20162017. The grapes used to produce the juices were of two varieties of Vitis labrusca, purchased from farmers of the rural area of Dom Pedrito and Santana do Livramento, municipalities of the Campanha Gaucha region, state of Rio Grande do Sul, Brazil. The raw materials for the juice extraction process were sent to the Laboratory of Microvinification of the course of Technology in Viticulture and Enology, which belongs to the Sul-Rio-Grandense Federal Institute, CAVG Campus, in Pelotas/RS, Brasil.

The experimental design was completely randomized, in a $2 \times 2$ factorial arrangement. The factors were: production location (Dom Pedrito and Santana do Livramento); and variety (Bordô and Concord). The four treatments were carried out with four replicates and each experimental unit consisted of a $1.5 \mathrm{~L}$ juice bottle.

Initially, the berries were manually separated from the stems and selected by rejecting the injured and unripe ones. The juices were elaborated using a stainless-steel steam juicer, which performs the extraction by passing a stream of steam through the berries. The selected berries were put in the most internal subdivision of the equipment (basically a colander) which is surrounded by a more external container (recipient of the extracted juice). Both parts were coupled on the lower container, which holds the boiling water to provide the necessary steam for the process. A gas burner, placed underlying the whole set, was used as source of heat.

The physico-chemical analysis took place in the laboratories of EPAGRI (Company of Agricultural Research and Rural Extension of Santa Catarina) Experimental Station of Videira, located in the state of Santa Catarina. The dependent variables evaluated were: total acidity (mEq.L $\mathrm{L}^{-1}$ ), volatile acidity (mEq. $\mathrm{L}^{-1}$ ), density, $\mathrm{pH}$, and total soluble solids ( ${ }^{\circ}$ Brix). The analytical methods followed the specifications of "Métodos de Análise de Bebidas Fermentadas, Destiladas, Não Alcoólicas e de Vinagre do Manual Operacional de Bebidas e Vinagre" aprooved by "Instrução Normativa $\mathrm{N}^{\circ} 24$, de 8 de Setembro de 2005, of Ministry of Agriculture, Livestock and Food Supply, Brazil. The color was determined by spectrophotometric measurements at $420,520,620 \mathrm{~nm}$, with quartz cuvette of $1 \mathrm{~mm}$ optical pace. Color intensity is represented by the relation between the values obtained at 420 and $520 \mathrm{~nm}$ [17].

The obtained data followed ANOVA, and Tukey's test (5\%) for comparison of means.

\section{Results and discussion}

Based on the results, the parameters total acidity and volatile acidity are in conformity with the Brazilian legislation. The regulation [18] determines a minimum total acidity of $55 \mathrm{mEq} \cdot \mathrm{L}^{-1}$ and a maximum volatile acidity of $10 \mathrm{mEq} \cdot \mathrm{L}^{-1}$. On Table 2 it is possible to observe that "Bordô" juices presented higher total acidity than "Concord" juices. This result is in accordance with the recent experiments of Canossa et al. [19], which compared "Bordô", "Concord", and "Isabel Precoce", noticing higher total acidity values for "Bordô" juices, in Lages, Santa Catarina, Brasil. The low volatile acidity 
Table 1. Mean values of total acidity (mEq. $\left.\mathrm{L}^{-1}\right)$, volatile acidity (mEq.L $\left.\mathrm{L}^{-1}\right)$, density, and $\mathrm{pH}$ for "Bordô" and "Concord" juices obtained from grapes produced in Dom Pedrito and Santana do Livramento, Rio Grande do Sul - Brazil. Pelotas, 2018.

\begin{tabular}{|c|c|c|}
\hline \multirow[b]{2}{*}{ Locations } & \multicolumn{2}{|c|}{ Total acidity $\left(\mathrm{mEq} \cdot \mathrm{L}^{-1}\right)$} \\
\hline & Bordô & Concord \\
\hline Dom Pedrito & 98.95 a NS & 88.82 b NS \\
\hline \multirow[t]{2}{*}{ Santana do Livramento } & $96.35 \mathrm{a}$ & $88.35 \mathrm{~b}$ \\
\hline & \multicolumn{2}{|c|}{ Volatile acidity (mEq. $\mathrm{L}^{-1}$ ) } \\
\hline Dom Pedrito & $1.90 \mathrm{~b}$ NS & 2.10 a NS \\
\hline \multirow[t]{2}{*}{ Santana do Livramento } & $1.57 \mathrm{~b}$ & $2.50 \mathrm{a}$ \\
\hline & \multicolumn{2}{|c|}{ Density $\left(\mathrm{g} \cdot \mathrm{mL}^{-1}\right)$} \\
\hline Dom Pedrito & $1049.25 \mathrm{NS}$ & $1055.75 \mathrm{NS}$ \\
\hline \multirow[t]{2}{*}{ Santana do Livramento } & $1053.25 \mathrm{NS}$ & 1054.25 \\
\hline & $\mathrm{pH}$ & \\
\hline Dom Pedrito & $3.59 \mathrm{~b} \mathrm{~A}$ & 3.67 a A \\
\hline Santana do Livramento & $3.45 \mathrm{~b} \mathrm{~B}$ & $3.63 \mathrm{a} \mathrm{B}$ \\
\hline
\end{tabular}

indicate that the raw materials were in optimal condition, without injuries or sanitary problems [20].

The values of density did not present statistically significant differences between the varieties and location, as shown in Table 1.

The highest $\mathrm{pH}$ mean value was found in "Bordô" juice from Dom Pedrito (Table 1). Similar results were found by Ferri et al. [21], who found a pH of 3.45 in "Bordô" juices from Pelotas, Rio Grande do Sul, Brazil.

Means followed by the same small letter within the lines and the same capital letters within the columns were not statistically different in a Tukey's test $(5 \%)$. NS $=$ Nonsignificant.

In general the results of total soluble solids were under $14^{\circ}$ Brix, the minimum limit stablished by Brazilian legislation. This fact can be due to the unavoidable addition of considerable amounts of water, originated from the condensation of steam, which is the main element of the steam juicer system to deliver heat and extract the grape component, such as the pigments [15]. Invariably, the values of total soluble solids found in this study for juices from Santana do Livramento (Table 2) were higher than those found by Rizzon and Link [15] for juices of the same grape varieties produced in Bento Gonçalves, Serra Gaucha. These same authors found average values of $12.2^{\circ}$ Brix for "Bordô" and $12.9^{\circ}$ Brix for "Concord" juices.

Grapes of both varieties from Santana do Livramento resulted in juices with higher color intensity, as displayed in Table 2. On the other hand, higher color hue was found in Dom Pedrito juices. The values found in this study for color intensity were lower than the values found by Canossa et al. [19]. These authors have observed averages of 11.86 and 12.77 for "Concord" and "Bordô" juices, respectively.

\section{Conclusion}

The variables variety and/or location impacted significantly on several physico-chemical aspects of the grape juices covered in this study, even though the raw materials were produced in two locations which are considered to belong to the same producing region, the Campanha Gaucha region.
Table 2. Mean values of total soluble solids $\left({ }^{\circ}\right.$ Brix), color intensity, and color hue for "Bordô" and "Concord" juices obtained from grapes produced in Dom Pedrito and Santana do Livramento, Rio Grande do Sul - Brazil. Pelotas, 2018.

\begin{tabular}{lll}
\hline \multirow{2}{*}{ Locations } & \multicolumn{2}{l}{ Soluble solids $\left({ }^{\circ}\right.$ Brix $)$} \\
\cline { 2 - 3 } & Bordô & Concord \\
\hline Dom Pedrito & $11.37 \mathrm{~b} \mathrm{~B}$ & $13.37 \mathrm{a} \mathrm{A}$ \\
\hline Santana do Livramento & 13.00 a A & 13.27 a A \\
\hline \multicolumn{3}{l}{ Color intensity } \\
\hline Dom Pedrito & 8.65 NS B & $7.78 \mathrm{~B}$ \\
\hline Santana do Livramento & 10.76 NS A & $11.39 \mathrm{~A}$ \\
\hline & Color hue \\
\hline Dom Pedrito & 6.08 NS A & $6.48 \mathrm{~A}$ \\
\hline Santana do Livramento & $5.99 \mathrm{NS} \mathrm{B}$ & $5.56 \mathrm{~B}$ \\
\hline
\end{tabular}

Means followed by the same small letter within the lines and the same capital letters within the columns were not statistically different in a Tukey's test $(5 \%)$. NS $=$ Non-significant.

This research was partially supported by FAPERGS (Research Support Foundation of the State of Rio Grande do Sul) and Coordination for the Improvement of Higher Education Personnel (CAPES).

\section{References}

[1] A. Troian, A.P. Arbage, Análise dos Sistemas de Produção Vitícola Familiar: a influência dos resultados econômicos na adoção dos Sistemas de Base Ecológica e Convencional na Serra Gaúcha-RS. Redes 20, 180-202 (2016)

[2] L.M.R. Mello, Vitivinicultura Brasileira: Panorama 2014, Bento Gonçalves: EMBRAPA Uva e Vinho. 2015 (Comunicado Técnico 175)

[3] C.C. Guerra, Sistema para elaboração de suco de uva integral em pequenos volumes: suquificador integral. Emprapa Uva e Vinho (2016)

[4] B. Dachery, V. Manfroi, J. Welke, Cienc. Rural 46, 1868 (2016)

[5] M.T.A. Santana, H.H. Siqueira, K.C. Reis, L.C.O. Lima, R.J.L. Silva, Ciênc. Agrotec. 32, 882 (2008)

[6] P.S. Ritschel, J.D.G. Maia, U.A. Camargo, Bento Gonçalves: Embrapa Uva e Vinho, 2011 (Documentos 72)

[7] G.W.B. de Melo, M. Botton, L. da R. Garrido. Produção Orgânica de Uva para Mesa, Embrapa Uva E Vinho 92 (2015)

[8] C.V. Rombaldi, V.C. Ferri, M. Bergamaschi, L. Luchetta, M.R. Zanuzo, Rev. Bras. de Agroc. 10, 519 (2004)

[9] E.A. Camargo, J. Tonietto, A. Hoffmann, Rev. Bras. Frutic. E., 144 (2011)

[10] J. Tonietto, V. Sotés, V. Gomez-Miguel, Clima, zonificación y tipicidad del vino en regiones vitivinícolas Iberoamericanas. CYTED, 411p (2012)

[11] V.B. Costa, Efeito das condições climáticas na fenologia da videira européia em Santana do Livramento, Rio Grande do Sul. Tese. 89f (2011)

[12] M.B. Sarmento, Diagnóstico da Vitivinicultura na Campanha Gaúcha: uma análise swot. Rev. Agropampa, 1, 65-85 (2016)

[13] C. Malacrida, S. Motta, Compostos fenólicos totais e antocianinas em suco de uva. Ciênc. Tecnol. Aliment. 25, 659-664 (2005) 
[14] L.A. Rizzon, V. Manfroi, J. Meneguzzo, Elaboração de suco na propriedade vitícola. Embrapa Uva e Vinho (1998)

[15] L.A. Rizzon, M. Link, Composição do suco de uva caseiro de diferentes cultivares. Ciênc. Rural 36, 689-692 (2006)

[16] S.S. Flores, Desenvolvimento territorial sustentável a partir da vitivinicultura: o caso dos "Vinhos da Campanha". 153 f. Dissertação (2011)

[17] P. Ribéreau-Gayon, Y. Glories, A. Maujean, D. Dubourdieu, Handbook of Enology: The Chemistry of Wine Stabilization and Treatments (John Wiley \& Sons, Ltd, 2006)
[18] Brasil. INSTRUÇÃO NORMATIVA $N^{\circ} 14$, DE 08 DE FEVEREIRO DE 2018. Complementação dos Padrões de Identidade e Qualidade do Vinho e Derivados da Uva e do Vinho (2018)

[19] A.T. Canossa, J. Reinehr, B.P. de Bem, R. Allenbandt, D.A. Wurz, A.A. Kretzchmar, Composição Química E Análise Sensorial Do Suco De Uva Elaborado Com Três Variedades Cultivadas Em Lages - Santa Catarina. Congrega (2017)

[20] M.C.P. Dutra, M.S. Lima, A.P.A. Barros, R.J. Mascarenhas, A. Lafisca, Rev. Bras. Prod. Agroind. 16, 265 (2014)

[21] V.C. Ferri, R.L. Sainz, P.S. Bandeira, Braz. J. Food Res. 8, 88 (2017) 